\begin{tabular}{|c|c|c|}
\hline \multirow[t]{3}{*}{ BENTHAM OPEN } & The Open Civil Engineering Journal & $\begin{array}{l}\text { The Open } \\
\text { Cril nngincecing } \\
\text { lournal }\end{array}$ \\
\hline & Content list available at: www.benthamopen.com/TOCIEJ/ & 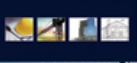 \\
\hline & DOI: $10.2174 / 1874149501610010905$ & \\
\hline
\end{tabular}

\title{
RETRACTION
}

\section{Retraction Notice: Study and Analysis of Human Survival Parameters in Mine Refuge Station}

Yang Zhe*, Jin Longzhe* and Wang Shu ${ }^{*}$

University of Science and Technology Beijing, P.O. Box 394, 30 Xueyuan Road, Haidian District, Beijing, P.R. China

\section{RETRACTION}

The Publisher and Editor have retracted this article [1] in accordance with good ethical practices. After thorough investigations we believe that the peer review process was compromised. The article was published online on 10-09-2015.

\section{REFERENCE}

[1] Y. Zhe, J. Longzhe, and W. Shu, "Study and analysis of human survival parameters in mine refuge station", Open Civ. Eng. J., vol. 9, pp. 650-656, 2015.

(C) Zhe et al.; Licensee Bentham Open.

This is an open access article licensed under the terms of the Creative Commons Attribution-Non-Commercial 4.0 International Public License (CC BY-NC 4.0) (https://creativecommons.org/licenses/by-nc/4.0/legalcode), which permits unrestricted, non-commercial use, distribution and reproduction in any medium, provided the work is properly cited.

* Address correspondence to these authors at the University of Science and Technology Beijing, P.O. Box 394, 30 Xueyuan Road, Haidian District, Beijing, P.R. China 100083; Tel: +86-18500194392; E-mail: ustbyz2012@126.com 